\title{
EFEKTIVITAS METODE PAIKEM DALAM PROSES PEMBELAJARAN JARAK JAUH KELAS III DI SDIT ASSA'ADAH GLOBAL ISLAMIC SCHOOL (AGIS)
}

\author{
Reksa Adya Pribadi ${ }^{1}$, Syifa Oktafia ${ }^{2}$, Nurlaela ${ }^{3}$ \\ 1,2,3 Universitas Sultan Ageng Tirtayasa, ${ }^{2}$ Universitas Sultan Ageng Tirtayasa, \\ ${ }^{1}$ reksapribadi@untirta.ac.id, ${ }^{2} 2227190041 @ u n t i r t a . a c . i d$, \\ 32227190041@untirta.ac.id
}

\begin{abstract}
This study aims to describe the use of the PAIKEM method (active, innovative, creative, effective and fun learning) in Distance Learning at the Assa'adah Global Islamic School (AGIS) school, especially in grade 3. The method used in this study, using an evaluation method with qualitative approach and descriptive method. Combined data collection techniques, data analysis is inductive in nature and utilizes various existing scientific methods and collects data. The results of the study indicate that the SDIT Assa'adah Global Islamic School teacher is one of the elementary schools located in Cipocok Jaya District, Serang City, Banjar Sari Village, Banten Province is said to be quite able to understand the PAIKEM learning model, it can be seen from the answers to questions asked proposed by the researcher.
\end{abstract}

Keywords: Effectiveness, PAIKEM, Distance Learning

\begin{abstract}
ABSTRAK
Penelitian ini bertujuan untuk mendeskripsikan penggunaan metode PAIKEM (pembelajaran aktif, inovatif, kreatif, efektif dan menyenangkan) dalam Pembelajaran Jarak Jauh di sekolah Assa'adah Global Islamic School (AGIS) khususnya dikelas 3. Metode yang digunakan dalam penelitian ini, menggunakan metode evaluasi dengan pendekatan kualitatif dan metode deskriptif. Teknik pengumpulan data gabungan, analisis data bersifat induktif dan memanfaatkan berbagai metode ilmiah yang ada serta mengumpulkan data. Hasil penelitian menunjukkan bahwa Guru SDIT Assa'adah Global IsImic School adalah salah satu sekolah dasar yang berada di Kecamatan Cipocok Jaya, Kota Serang, Kelurahan Banjar Sari, Provinsi Banten dikatakan cukup mampu memahami model pembelajaran PAIKEM, hal itu bisa dilihat dari jawaban atas pertanyaan yang diajukan oleh peneliti.
\end{abstract}

Kata Kunci: Efektivitas, PAIKEM, Pembelajaran Jarak Jauh

\section{A. Pendahuluan}

Pandemi Covid -19 telah mempengaruhi kehidupan di negara Indonesia sendiri baik di bidang ekonomi, politik, kesehatan bahkan pendidikan. 
Dalam bidang pendidikan, sistem pembelajaran dilakukan dari jarak jauh melalui pemanfaatan teknologi informasi. Namun, terdapat tantangan utama dalam menerapkan model pembelajaran jarak jauh. Salah satunya belum terbiasanya menggunakan sistem online, karena proses pengajarannya lebih dibiasakan menggunakan metode tatap muka. Oleh karena itu guru harus terlebih dahulu mengubah capaian target, kemudian mengubah metode pembelajaran agar cepat beradaptasi dengan situasi ini.

Dalam pembelajaran jarak jauh, guru harus lebih aktif memberikan stimulasi kepada siswa, agar tetap semangat mengikuti pembelajaran. Diharapkan para siswa akan mendapatkan pembelajaran dengan skala yang sama seperti ketika mereka belajar di sekolah. Tugas pendidik bukan hanya sekedar transfer ilmu, tetapi juga tugas guru sebagai pendidik dan motivator, membimbing ke arah yang lebih baik terutama dalam pembentukan akhlak (sikap) siswa. Pendidikan diharapkan oleh siswa berbakat yang memiliki karakter yang baik dan menggunakan siswa berbakat melalui kinerja atau perilaku yang baik.
Pendidik harus bisa berinovasi dalam dunia pendidikan, salah satunya adalah memilih metode pembelajaran atau membuat metode baru yang sesuai bagi siswa agar proses pembelajaran dapat terlaksana dengan efektif dan membuahkan hasil yang diharapkan. Pendidik harus memiliki empat kemampuan dalam menjalankan tugasnya. Salah satunya adalah kemampuan profesional, untuk itu pendidik harus memiliki kemampuan mengikuti perkembangan zaman. Pendidik yang berbakat harus bisa melihat hal tersebut dan memanfaatkan kemajuan teknologi yang ada. Namun kenyataannya sebagian besar pendidik belum dapat mengembangkan keterampilannya, terutama dalam hal tanggung jawab selama proses pembelajaran. Hal tersebut terlihat dari banyaknya tenaga pendidik dan dosen yang menggunakan metode pembelajaran yang monoton hanya terdapat satu metode yaitu metode ceramah.

Guru SD dituntut untuk lebih kreatif melalui metode-metode yang digunakan dalam proses pembelajaran. Salah satu metode yang dapat digunakan adalah metode PAIKEM (pembelajaran aktif, inovatif, 
kreatif, efektif dan menyenangkan). Metode PAIKEM mendorong siswa untuk lebih aktif dan membuat kelas menjadi lebih menyenangkan. Pembelajaran PAIKEM sendiri merupakan pembelajaran yang berpusat pada siswa yang mengembangkan keterampilan dan pemahaman melalui berbagai kegiatan, Oleh karena itu model pembelajaran ini sangat penting bagi pendidik dan peserta didik. Selain itu, guru juga dituntut untuk menciptakan suasana kelas agar siswa secara aktif mengajukan, mempertanyakan dan mengungkapkan gagasannya.

Untuk menggunakan metode PAIKEM dalam pembelajaran, guru harus memiliki kreativitas dan kepribadian, dan guru yang kreatif harus memiliki ciri-ciri sebagai berikut: Kefasihan artinya guru dapat mengemukakan ide-ide yang tepat berdasarkan masalah yang dihadapi. Fleksibilitas artinya guru bisa berpikiran terbuka. Orisinalitas berarti mampu menciptakan ide-ide baru. Penjelasan rinci berarti guru dapat melihat masalah secara detail. Guru yang kreatif adalah guru yang dapat menghasilkan ide-ide baru, terbuka terhadap guru dan siswanya, serta dapat memecahkan masalah. Guru karakter adalah guru yang menjunjung tinggi nilai moral, akhlak, agama, dan nilai kewarganegaraan.

Namun pada kenyataannya masih banyak guru yang kurang memiliki kreativitas dan kepribadian untuk belajar, guru Aktif, Inovatif, Kreatif, Efektif dan Menyenangkan (PAIKEM) sehingga metode ini kurang berjalan dengan baik. Dan metode ini biasanya tidak diterapkan, karena membutuhkan alat peraga yang banyak, sehingga sangat merepotkan, dan terkadang membuat guru kurang tertarik dengan metode pembelajaran PAIKEM ini. Beberapa guru menganggap bahwa model pembelajaran ini adalah model pembelajaran yang mahal sehingga efek implementasinya tidak efektif digunakan di sekolah.

Dalam penerapan metode ini pendidik dituntut untuk menciptakan suasana pembelajaran yang aktif, inovatif, kreatif, efektif, dan menarik, untuk mewujudkan suasana tersebut di sekolah Assa'adah Global Islamic School (AGIS) khususnya dikelas 3 dalam penggunaan metode ini masih jarang diimplementasikan dalam proses pembelajaran karena kurangnya kemampuan guru dalam menggunakan metode ini dan 
dikarenakan guru lebih sering memakai metode yang tidak merepotkan dan tidak membutuhkan alat peraga yang cukup untuk menunjang proses pembelajaran PAIKEM dan kurangnya partisipasi dari orang tua wali murid, dengan banyaknya kendala yang dihadapi, proses pembelajaran PAIKEM di sekolah Assa'adah Global Islamic School (AGIS) tidak terlaksana dengan baik.

Berdasarkan latar belakang diatas maka peneliti merumusakan masalah yaitu:

1. Bagaimana proses implementasi metode PAIKEM dalam proses pembelajaran jarak jauh ?

2. Bagaimana dampak implementasi metode PAIKEM dalam proses pembelajaran jarak jauh ?

Berdasarkan rumusan masalah diatas, maka selanjutnya penelitian ini bertujuan

1. Untuk mengetahui bagaimana proses implementasi metode PAIKEM dalam proses pembelajaran jarak jauh.

2. Untuk mengetahui bagaimana dampak implementasi metode PAIKEM dalam proses pembelajaran jarak jauh.

\section{B. Metode Penelitian}

Dalam penelitian ini, metode yang digunakan evaluasi dalam pendekatan kualitatif dan metode deskriptif. Dalam kegiatan penelitian ini peneliti akan mencoba untuk menggambarkan seluruh peristiwa maupun fenomena yang terjadi selama proses penelitian, terutama peristiwa yang berhubungan dengan tujuan dan fokus penelitian. Pendekatan kualitatif merupakan pendekatan yang sangat relevan untuk mempelajari fenomena yang terjadi di masyarakat, karena observasi dilakukan untuk latar belakang dan individu, dan mereka dianggap sebagai bagian dari keseluruhan, bukan berdasarkan variabel atau asumsi oleh karena itu, melalui pendekatan kualitatif penelitian yang dilakukan dapat memperoleh informasi yang lebih jelas tentang kondisi, situasi dan kejadian (Maleong, 2010:3).

\section{Data kualitatif memberikan} deskripsi yang mendetail, dan dapat menangkap perbedaan versi di antara peristiwa. Hal ini didasarkan pada sudut pandang Patton. la mengatakan bahwa penelitian kualitatif dalam studi evaluasi ini dapat memberikan gambaran penting 
dari keseluruhan rencana, antara lain: deskripsi rinci tentang pelaksanaan rencana, analisis proses pelaksanaan rencana, perbedaan antara peserta dan jenis partisipasi peserta dalam pencapaian perubahan rencana dan menganalisis kelemahan dan kekuatan rencana.

Dalam Pengumpulan data, peneliti menggunakan dua teknik pengumpulan data, yaitu studi obeservasi dan wawancara. Dalam penelitian ini peneliti akan menggunakan metode observasi yaitu observasi tidak terstrukturi. Menurut (Sugiyono, 2014:228) Pengamatan yang dilakukan menggunakan pengamatan berstruktur yaitu dengan melakukan pengamatan menggunakan pedoman observasi pada saat pengamatan dilakukan. Pengamatan ini dilakukan saat subyek melakukan kegiatan belajar mengajar dan pada saat jalannya wawancara.

Menurut Estenberg, wawancara merupakan pertemuan dua orang untuk bertukar informasi dan ide melalui tanya jawab sehingga dapat dikonstruksikan makna dalam suatu topik tertentu (Sugiyono, 2014:231). Seperti halnya observasi, wawancara juga memiliki beberapa macam jenis.
Wawancara yang akan dilakukan adalah wawancara semiterstruktur, yang merupakan jenis wawancara indepth interview. Hal ini dikarenakan, wawancara ini bertujuan untuk menemukan masalah secara lebih terbuka, di mana pihak yang diajak wawancara dimintai pendapat, dan ide-idenya (Sugiyono, 2014:233).

\section{Hasil Penelitian dan Pembahasan}

Hasil penelitian yang dilaksanakan di SD Assa'adah Global Islmic School tepatnya kelas III A. SD Assa'adah Global IsImic School adalah salah satu sekolah dasar yang berada di Kecamatan Cipocok Jaya, Kota Serang, Kelurahan Banjar Sari, Provinsi Banten. Sekolah Dasar yang berstatus swasta ini memiliki luas lahan $1,815 \mathrm{~m}^{2}$ dan telah terakreditasi Adapun penelitian kami dilaksanakan di kelas III A dengan wali kelasnya adalah Ibu Indri Aprilia, S.Pd.

\section{Untuk mengetahui bagaimana proses implementasi metode PAIKEM dalam proses pembelajaran jarak jauh.}

Adanya tujuan ini peneliti dapat mengetahui bagaimana proses implementasi metode PAIKEM dalam proses pembelajaran jarak jauh. 
Pembelajaran berbasis PAIKEM itu sendiri merupakan sebuah pembelajaran yang memungkinkan siswa untuk mengerjakan kegiatan yang beragam dalam rangka mengembangkan keterampilan dan pemahamannya, dengan penekanan siswa belajar sambil bekerja, sementara guru menggunakan berbagai sumber dan alat bantu belajar (termasuk pemanfaatan lingkungan), supaya pembelajaran lebih menarik, menyenangkan dan efektif. Guru berupaya secara kreatif mencoba berbagai cara untuk melibatkan semua siswa dalam kegiatan pembelajaran. Sementara siswa dituntut kreatif untuk memperoleh pengetahuan dan berinteraksi dengan sesama teman, guru, maupun bahan ajar dengan segala perangkatnya. Untuk itu, maka dalam proses implementasi pembelajaran PAIKEM harus dapat menciptakan pembelajaran sebagai berikut :

\section{a) Mengetahui Apakah Guru Menguasai pembelajaran Aktif, Inovatif, Kreatif dan Efektif serta Menyenangkan}

1. Pembelajaran yang aktif

Dalam proses pembelajaran yang aktif itu terjadi dialog yang interaktif antara siswa dengan siswa, siswa dengan guru atau siswa dengan sumber belajar lainnya. Dalam suasana pembelajaran yang aktif tersebut, siswa tidak terbebani secara perseorangan dalam memecahkan masalah yang dihadapi dalam belajar, tetapi mereka dapat saling bertanya dan berdiskusi sehingga beban belajar bagi mereka sama sekali tidak terjadi.

Menurut Aswan

(2016:44)

pembelajaran aktif adalah suatu pembelajaran yang mengajak peserta didik untuk belajar secara aktif. Ketika peserta didik belajar dengan aktif, berarti mereka yang mendominasi aktivitas dalam pembelajaran. Sejalan dengan itu Hariwibowo dan Kristiawan (2016:6) menjelaskan bahwa pembelajaran aktif mengandung makna bahwa sebuah proses belajar harus dapat menumbuhkan motivasi dalam diri siswa untuk terlibat secara aktif. Jadi dapat disimpulkan bahwa pembelajaran aktif adalah suatu pembelajaran yang mengajak peserta didik dan menumbuhkan motivasi untuk belajar secara aktif dan proses belajar harus dapat dalam diri siswa untuk terlibat secara aktif. 
Ibu Indri selaku guru yang mengajar kelas 3 disekolah tersebut sudah menciptakan pembelajaran yang aktif beliau selalu memberikan evaluasi kepada siswa setelah pembelajaran selesai evaluasi yang dilakukan yakni dengan memberikan pertanyaaan terkait materi kepada siswa, dalam hal ini siswa dituntut untuk aktif , dalam hal ini pula terjadi interaksi antar guru dengan siswa.

\section{Pembelajaran Inovatif}

Inovatif dapat diartikan sebagai pengenalan hal-hal baru. Pembelajaran yang inovatif bagi guru dapat digunakan untuk menerapkan temuan-temuan terbaru dalam pembelajaran, terlebih lagi jika temuan itu merupakan temuan guru yang pernah ditemukan dalam penelitian tindakan kelas atau sejumlah pengalaman yang telah ditemukan selama menjadi guru.

Menurut Aswan (2016:46) Pembelajaran inovatif adalah pembelajaran yang mengembangkan kemampuan peserta didik untuk melahirkan pemikiran atau ide-ide sendiri yang biasanya dapat muncul dari situasi pembelajaran kondusif dan bebas dari perasaan tertekan, takut atau cemas. Sejalan dengan itu Purwadhi (2019:21) menjelaskan bahwa Pembelajaran Inovatif mengandung arti pembelajaran yang dikemas oleh guru, atau instruktur, yang merupakan wujud gagasan atau teknik yang dipandangn baru, agar mampu memfasilitasi siswa untuk memperoleh kemajuan dalam proses dan hasil belajar.

Jadi Pembelajaran inovatif adalah pembelajaran yang mengembangkan kemampuan peserta didik untuk melahirkan dan mengemukakan pemikiran atau ideide baru dari dirinya sendiri untuk perbaikan atau pengembangan kegiatan pembelajaran dalam rangka pencapaian tujuan pembelajaran.

\section{Pembelajaran Kreatif}

Pembelajaran yang kreatif juga sebagai salah satu strategi yang mendorong siswa untuk lebih bebas mempelajari makna yang dia pelajari. Rosdijati (2010:19) menjelaskan bahwa pembelajaran kreatif mengandung arti bahwa seorang guru harus dapat menciptakan kegiatan belajar yang beragam sehingga memenuhi berbagai tingkat kemampuan siswa. Kemudian Aswan (2016:46) Pembelajaran kreatif adalah pembelajaran yang mampu menciptakan peserta didik lebih aktif, berani menyampaikan pendapat dan 
berargumen, meyampaikan masalah atau solusinya serta memperdayakan semua potensi yang sudah tersedia. Jadi dapat disimpulkan bahwa Pembelajaran Kreatif adalah pembelajaran yang mampu menciptakan peserta didik lebih aktif dan mengembangkan kemampuan berpikir siswa.

Peneliti melihat untuk dapat menciptakan pembalajaran yang kreatif ini, bu Indri melakukan pembelajaran yang kreatif, terlihat pada saat pemberian tugas pada materi bahasa indonesia bu indri meminta siswa untuk dapat memeragakan ungkapan atau kalimat saran, masukan, dan penyelesaian masalah (sederhana) sebagai bentuk ungkapan diri menggunakan kosakata baku dan kalimat efektif yang dibuat sendiri. Hal ini dituntut siswa untuk dapat kreatif dalam mengemukakan jawabannya.

\section{Pembelajaran Efektif}

Istilah efektif berarti model pembelajaran apapun yang dipilih harus menjamin bahwa tujuan pembelajaran akan tercapai secara maksimal. Situasi belajar yang aktif dan menyenangkan tidaklah cukup jika proses pembelajaran tersebut tidak efektif, yaitu tidak menghasilkan apa yang seharusnya dikuasai siswa setelah proses pembelajaran berlangsung.

Uno dan Mohammad (2011:12) menjabarkan pembelajaran yang efektif adalah salah satu strategi pembelajaran yang diterapkan guru dengan maksud untuk menghasilkan tujuan yang telah ditetapkan. Sejalan dengan itu Dede Rohaniawati (2016:160) mengungkapkan bahwa pembelajaran yang efektif ini adalah strategi pembelajaran yang diadopsi oleh guru untuk mencapai tujuan yang telah ditetapkan. Jadi dapat disimpulkan bahwa pembelajaran efektif adalah strategi pembelajaran yang diadopsi oleh guru untuk mencapai tujuan suatu kompetensi rancangan pembelajaran.

Dalam proses pembelajarannya terlihat bahwa bu Indri untuk menciptakan pembalajaran yang efektif, beliau menggunakan strategi pembelajaran dengan mengunakan metode-metode yang beliau gunakan dalam mengajar dikelas, hal ini dilakukan agar tujuan pembelajaran dapat tercapai.

5. Pembelajaran Menyenangkan

Saat siswa sedang senang, proses belajar akan mudah diterima dan dipahami. Kesenangan semacam 
ini akan menghasilkan emosi, artinya ketika siswa berhasil membangkitkan rasa senang pada konten yang dipelajarinya, mereka akan memiliki emosi selama pelajaran yang dipelajarinya. Jika mereka menyukainya, mereka akan rela melakukan apapun untuk apa yang mereka pedulikan. Timbul motivasi dalam diri siswa yang mengantarkan rasa keingin tahuan yang disertai kemuan untuk mencari tahu.

Muhammad Noor (2010:18) menjelaskan bahwa suasana belajar mengajar yang dapat memusatkan perhatiannya secara penuh saat belajar sehingga curah waktu perhatiannya (time on task) tinggi. Sejalan dengan itu Pembelajaran Menyenangkan menurut Zulviana Trinova (2012:210) suasana pengajaran dimana siswa dapat berkonsentrasi penuh selama proses pembelajaran, sehingga waktu konsentrasi sangat tinggi. Jadi dapat disimpulkan bahwa pembelajaran yang menyenangkan adalah pembelajaran yang dapat menarik perhatian siswa dengan berbagai metode yang diterapkan, sehingga saat pembelajaran berlangsung siswa tidak merasa bosan.
Dalam

menciptakan

pembelajaran yang menyenangkan Ibu Indri melakukan sebelum pembelajaran dimulai bu indri selalu mengajak anak-anak untuk bernyanyi bersama - saama, hal ini pun ibu indri lakukan agar proses belajar mengajar menjadi menyenangkan, terlihat ketika anak - anak bernyanyi bersama- sama mereka sangat semangat. Dalam menyampaikan materi beliau selalu menampilkan video pembelajaran yang menarik dan siswa pun menjadi antusias dalam mengikuti proses pembelajaran terlihat saat siswa sangat semangat.

\section{Mengetahui Pemilihan Metode Pembelajaran}

Dalam kegiatan mengajar diperlukan metode pembelajaran yang menarik agar siswa tidak bosan dengan apa yang diajarkan guru. Metode pembelajaran dapat diartikan sebagai metode pelaksanaan rencana yang disusun dalam bentuk kegiatan aktual dan praktis untuk mencapai tujuan pembelajaran. Biasanya metode pembelajaran klasikal hanya menitikberatkan pada satu aspek yaitu aspek penyampaian informasi. Sekaligus sebagai pendidik profesional, pendidik harus mampu 
menstimulasi proses berfikir, membantu menumbuhkan sikap kritis, dan mampu mengubah pola pikir peserta didik. Oleh karena itu, perlu digunakan bentuk atau metode pengajaran lain yang lebih efektif. Menurut Wina (2011: 148), metode pembelajaran dapat digunakan sebagai model seleksi, artinya guru dapat memilih metode pembelajaran yang tepat dan efisien untuk mencapai tujuan pendidikan. Seorang guru juga harus mampu menerapkan metode pembelajaran yang bervariasi agar pembelajaran yang berlangsung tidak monoton dan Penggunaan metode pembelajaran juga penting karena metode pembelajaran itu adalah teknik yang dikuasai guru untuk menyampaikan materi pembelajaran dikelas, jadi cepat pahamnya tidaknya anak itu tergantung metode yang diaplikasikan. Metode pembelajaran yang digunakan guru harus dapat mewujudkan hasil karya siswa.

Bimbing siswa untuk berpikir kritis dan kreatif dengan memberikan kesempatan kepada siswa untuk mengungkapkan gagasannya. Metode yang dipilih kurang tepat akan berpengarauh pada materi dan tujuan pembelajaran yang akan mengurangi semangat kelas dan kondisi siswa menjadi kurang kreatif. Oleh karena itu, penggunaan metode yang benar dengan berbagai indikator dapat meningkatkan minat siswa terhadap topik yang disampaikan, dan minat akhir akan berpengaruh pada prestasi yang ingin dicapai.

Sejalan dengan penelitian yang peneliti lakukan pada siswa kelas III di SDIT AGIS dengan wali kelas bu Indri Aprillia, Menurut bu indri metode pembelajaran ada banyak sekali seperti yang sering beliau gunakan yaitu demonstrasi, cermah, penugasan dan sebagainya. Akan tetapi bu indri menggunakan metode pembelajaran itu disesuaikan dengan kebutuhan yang ingin disampaikan, karana menurut bu indri Metode atau model yang tepat bisa memberikan efek yang maksimal terhadap pencapain pembelajaran yang diinginkan agar tujuannya dapat tercapai. Untuk melihat berhasil atau tidaknya metode yang lbu Indri terapkan, Beliau melihatnya dari pemahaman peserta didik, apakah peserta didik ini cepat pahamnya dengan materinya, jika tidak berarti ada yang salah dengan metode yang digunakannnya. 
2. Untuk Mengetahui Bagaimana Dampak Implementasi Metode Paikem Dalam Proses Pembelajaran Jarak Jauh di Dikelas III Assa'adah Global Islamic School (AGIS)

Berdasarkan pada hasil penelitian yang peneliti lakukan di SDIT AGIS dengan peneliti melakukan wawancara sekaligus observasai kepada Ibu Indri Aprillia S.Pd yaitu guru wali kelas III (tiga) untuk mengetahui bagaimana dampak dari implementasi metode paikem dalam proses pembelajaran jarak jauh yang diterapkan pada kelas III SDIT AGIS. Dapat peneliti peroleh hasil atau dampaknya dari implementasi penggunaan metode paikem di kelas III SDIT AGIS ini sebagai berikut :

a. Siswa Menunjukan rasa percaya diri (kemampuan bertanya, menjawab dan terampil dalam mengutarakan pendapatnya)

Kepercayaan diri menurut (Muhammad Anwar. 2018: 62-64) adalah keyakinan seseorang bahwa ia dapat menunjukkan kemampuannya dengan baik di hadapan orang lain. Banyak bukti yang menunjukkan bahwa rasa percaya diri siswa bukanlah suatu bakat (dilihat dari kekhususannya yang berbeda), melainkan suatu kualitas psikologis (hasil proses pendidikan atau pemberdayaan). Artinya, semua siswa dapat dilatih dan dididik sesuai dengan situasi agar lebih percaya diri. Secara umum, siswa dengan kepercayaan diri lebih mungkin berhasil daripada siswa tanpa kepercayaan diri. Ini terkait dengan poin-poin berikut.

Pertama, rasa percaya diri siswa berkaitan dengan pilihan sikap mentalnya terhadap tugas atau tantangan yang akan diselesaikan. Seseorang atau siswa dengan tingkat kepercayaan diri yang tinggi akan memilih sikap mental "Saya bisa". Di sisi lain, jika kepercayaan diri siswa sangat rendah, bahkan jika mereka bisa merasa sulit, "tidak bisa", "takut akan kesalahan" dan berbagai ekspresi serupa, mereka tidak berani memahami pemahaman ketika orang lain harus muncul di hadapan mereka.

Kedua, rasa percaya diri siswa akan terkait dengan konsep yang mereka bangun saat menghadapi tugas atau tantangan. Siswa yang percaya diri berpikir bahwa tantangan atau tugas lebih kecil dari kemampuan mereka, sehingga 
mudah merasa bersemangat untuk mengatasinya.

Ketiga, rasa percaya diri siswa berkaitan dengan gejala psikologis pengendalian fokus. Selama manusia hidup di dunia ini pasti akan menghadapi hal-hal yang tidak dapat diubah atau hal-hal yang biasa disebut takdir. Siswa yang percaya diri akan menyadari sedapat mungkin bahwa takdirnya lebih bergantung pada pilihannya atau mempertahankan fokus kendali pada pikiran dirinya sendiri. Menurutnya, setiap keputusan pasti ada konsekuensinya, namun jika dilakukan dan gagal akan lebih baik daripada tidak sama sekali. Dengan mengambil keputusan, siswa tidak hanya akan bergantung pada lingkungan, pada keberuntungan atau pada orang lain.

Beberapa hal yang dapat membentuk Kepercayaan Diri Siswa: Pertama adalah pengalaman hidup. Pengalaman menempati urutan teratas untuk meningkatkan kepercayaan diri. Untuk menumbuhkan kepercayaan diri, guru perlu membantu siswa menciptakan pengalaman baik sebanyak mungkin, dari hal kecil hingga hal besar dan berkesan. Kedua, contoh atau model.
Guru dapat memberikan contoh kepada siswa untuk menggambarkan keberhasilan kakak tingkat ataupun adik tingkat di sekolah dalam studi mereka. Guru juga dapat memberikan contoh, misalnya guru akhirnya berhasil menyelesaikan masalah setelah mengadopsi berbagai metode, atau menunjukkan bahwa guru tidak mudah merasa terkendala dan mudah menyerah. Ketiga, persuasif sosial. Evaluasi atau pengakuan positif guru di dalam kelas akan semakin meningkatkan rasa percaya diri siswa. Seperti "Ayo coba lagi, saya tahu kamu bisa melakukannya." Maksud ungkapan ini adalah untuk menciptakan motivasi yang positif. Keempat, faktor psikologis. Dibandingkan dengan siswa yang cemas, siswa yang memiliki kondisi jiwa yang baik, merasa nyaman dengan pakaian yang dikenakan, nyaman dengan penampilan dan lebih mudah membangun rasa percaya diri. Karena dengan siswa yang jiwanya sedang gelisah. Mereka banyak memikirkan hal-hal yang berkaitan dengan penampilan wajah, warna pakaian atau gaya rambut.

Musrini (2016:10) berpendapat bahwa pembelajaran adalah proses 
mengubah perilaku yang diperoleh melalui pengalaman individu yang bersangkutan. Proses pembelajaran kegiatannya merupakan suatu bentuk interaksi antara belajar mengajar dalam suasana interaksi pendidikan, yaitu interaksi pemahaman tujuan, artinya interaksi yang direncanakan untuk suatu tujuan tertentu sekurangkurangnya merupakan perwujudan tujuan belajar mengajar atau tujuan pembelajaran yang ditetapkan dalam satuan pembelajaran tersebut. Sedangkan menurut Johni Dimyati (2017:2) menjelaskan bahwa pembelajaran pada hakikatnya merupakan interaksi antara guru (pendidik) dan siswa (siswa). Dari pengertian diatas dapat disimpulkan bahwa pembelajaran merupakan suatu proses interaksi antara guru dan siswa, dan akibatnya melalui pengalaman pribadi (sistem terdiri dari beberapa komponen yang saling terkait), perubahan perilaku diperoleh melalui pengalaman individu.

Sejalan dengan yang peneliti telah amati dalam proses pembelajaran jarak jauh yang sedang peserta didik kelas III jalankan, Ibu Indri mengatakan bahwa anak-anak kelas III juga telah berani mengeluarkan pendapatnya dan juga telah dapat menjawab pertanyaan spontan yang diberikan oleh guru. Menurut beliau, itu karena anak-anak diusia kelas tiga, yang mana rata-rata telah berusia 9 tahun telah memiliki banyak teman dikelasnya. Dan yang terpenting sebenarnya ini tergantung dengan karakter anak-anak itu sendiri. Jika ada perbedaan pendapat didalam kelas Ibu Indri juga menjelaskan bahwa anak-anak telah dapat menerimanya. Beliau menjelaskan jika ada perbedaan pendapat dikelas, siswa saling berbagi dan bertanya mengapa jawaban mereka bisa berbeda. Beliau menjelaskan bahwa siswa kelas III juga telah dapat menyimpulkan pembelajaran yang telah berlangsung. Biasanya beliau akan memilih random anak-anak yang akan menyimpulkan materi pembelajaran jika melalui zoom. Beliau mengungkapkan bahwa siswa juga telah berani untuk maju kedepan kelas atau mengeluarkan pendapatnya didepan temantemannya.

Hal ini sesuai dengan pembelajaran yang merupakan suatu proses interaksi antara guru dan siswa, dan akibatnya melalui pengalaman pribadi (sistem terdiri 
dari beberapa komponen yang saling terkait), perubahan perilaku diperoleh melalui pengalaman individu maka dari itu hasil observasi tersebut peneliti dapat simpulkan siswa kelas III di SDIT AGIS telah menunjukan rasa percaya diri (kemampuan bertanya, menjawab dan terampil dalam mengutarakan pendapatnya).

b. Siswa senang saat melaksanakan proses pembelajaran

\section{Pembelajaran}

menyenangkan membutuhkan pemahaman yang luas. Belajar yang menyenangkan berarti lebih dari sekedar bernyanyi, bermain dan bercanda. Pembelajaran yang menyenangkan juga harus memberikan rasa aman, nyaman dan menyenangkan. Bila siswa senang, proses pembelajaran akan mudah diterima dan dipahami. Kesenangan semacam ini menimbulkan emosi, artinya ketika siswa berhasil membangkitkan kesenangan pada konten yang dipelajarinya, mereka akan membangkitkan emosi dalam mata pelajaran yang mereka pelajari. Oleh karena itu, belajar bukan lagi merupakan kegiatan yang harus dituntut sejak awal, melainkan kesadaran yang dihasilkan sendiri tanpa adanya kekuatan eksternal.
Sejalan dengan penelitian yang peneliti lakukan pada siswa kelas III di SDIT AGIS dengan wali kelas bu Indri Aprillia, Ibu Indri mengungkapkan bahwa hampir sebagian siswa masuk tepat waktu selama pembelajaran berlangsung, untuk mereka yang tidak dapat masuk tepat waktu biasanya mereka memiliki alasan khusus. Ada yang ingin belajar jika hanya bersama orang tuanya karena itu biasanya siswa itu mengambil kelas di malam hari ketika orang tuanya telah pulang bekerja. Selama pembelajaran jarak jauh juga, Beliau mengungkapkan bahwa anak-anak juga selalu menyiapkan keperluan belajarnya seperti buku ajar, buku tulis, keperluan menulis dan sebagainya. Ibu Indri juga mengatakan bahwa selama ia mengajar anak-anak juga menyukai media yang ia gunakan.

$\mathrm{Bu}$ Indri menjelaskan bahwa media yang dipakai haruslah semenarik mungkin agar anak-anak semanagat untuk belajar. Jika menggunakan power point harus dihias semenarik mungkin dengan menambahkan animasi agar siswa semangat belajar hal itu berlaku pula dengan video pembelajaran yang di share di Youtube. Beliau menjelaskan 
lagi dalam metode yang digunakan untuk pembelajaran jarak jauh juga siswa dapat beradaptasi jika orang tua dapat membantu mereka. Biasanya guru akan memberikan tutorial berupa video dan akan di share kepada orang tua murid. Ibu Indri juga menjelaskan bahwa selama pembelajaran jarak jauh siswa tetap menanyakan materi yang tidak mereka pahami secara rutin melalui voice note ataupun bertanya lansung selama pembelajaran berlangsung.

Ibu Indri menjelaskan bahwa banyak orang tua murid yang telah ingin melakukan pembelajaran offline, sebenarnya guru juga ingin karena menurut beliau pembelajaran offline tidak terlalu efektif karena saat pembelajaran jarak jauh tugas yang siswa kerjakan tidak dapat terlihat apakah siswa itu mengerjakan sendiri ataukah dibantu oleh orang dewasa. Jadi saat pembelajaran jarak jauh ini anak-anak memiliki nilai akademik yang kurang bisa memiliki nilai yang tinggi, yang mana saat pembelajaran offline biasanya akan ada remedial dan lain-lain untuk mereka. Karena itu Ibu Indri menjelaskan bahwa selama pembelajaran jarak jauh nilai itu bukanlah sebuah patokan.
Dengan demikian

dapat disimpulkan bahwa pembelajaran yang menarik adalah pembelajaran yang dapat menarik perhatian siswa melalui berbagai metode aplikasi, sehingga siswa tidak akan merasa bosan saat belajar. Dalam pembelajaran terdapat hubungan yang kuat antara guru dan siswa. Pembelajaran yang menarik memungkinkan siswa berkonsentrasi penuh saat belajar, sehingga menghabiskan waktu yang lama di tempat kerja.

\section{Kesimpulan}

Berdasarkan hasil penelitian dan pembahasan yang telah disajikan, maka dapat ditarik kesimpulan sebagai berikut: Metode pembelajaran merupakan suatu rencana atau pola yang dapat dipilih oleh guru dan dapat digunakan sebagai pedoman pembelajaran di kelas untuk menunjang keberhasilan proses pembelajaran. Guru dituntut untuk mengembangkan kegiatan pembelajaran yang memungkinkan siswa berpartisipasi melalui kegiatan yang partisipatif, aktif, inovatif, kreatif, efektif dan menyenangkan, sehingga siswa dapat menciptakan karya, pemikiran, wawasan dan gagasan 
berdasarkan penemuan dan usahanya sendiri, melainkan tidak dibuat oleh guru.

Dapat disimpulkan bahwa Guru SDIT Assa'adah Global IsImic School adalah salah satu sekolah dasar yang berada di Kecamatan Cipocok Jaya, Kota Serang, Kelurahan Banjar Sari, Provinsi Banten dikatakan cukup mampu memahami model pembelajaran PAIKEM, hal itu bisa dilihat dari jawaban atas pertanyaan yang diajukan oleh peneliti.

\section{DAFTAR PUSTAKA}

Khuluqo, El Ihsan. (2017). Belajar dan Pembelajaran.Yogyakarta : PUSTAKA PELAJAR

Sanjaya, Wina (2008). Kurikulum dan Pembelajaran . Jakarta : Kencana Pranada Media Group.

Mudhofir, Ali (2016). Desain Pembelajaran Inovatif. Depok : PT Raja Grofindo Persada.

Hermawan, Asep Herry. (2007). Belajar dan Pembelajaran SD. Bndung : Upi Press.

Musrini. (2016). Pembelajaran Kooperatif Tipe Explict Instruction. Purwekerto: Bebook Publisher
Rusman. (2017). Belajar dan Pembelajaran Berorientasi Standar Proses Pendidikan. Jakarta: PT Kharisma Putra Utama

Dimyati, Johni. (2016). Pembelajaran Terpadu Untuk KanakKanak/Raudatul Atfal dan Sekolah Dasar. Jakarta: Prenada Media.

Noor, Muhammad (2010). Pembelajaran Aktif Inovtif Kreatif Efektif Menyenangkan Gembira dan Berbobot (PAIKEM GEMBROT). Jakarta: PT Multi Kreasi Satu Delapan.

Aswan. (2016). Strategi Pembelajaran Berbasis PAIKEM (Edisi Revisi). Yogyakarta: Aswaja Pressindo.

Yaumi, Muhammad, M.Hum. (2018). Media dan Teknologi Pembelajaran Edisi Pertama. Jakarta: Kencana.

Mawardi, Pitalis. (2020). Penelitian

Tindakan Kelas, Penelitian Tindakan Sekolah Dan Best Practice (Suatu Panduan Praktis Bagi Guru dan Kepala Sekolah). Pasuruan: CV. Penerbit Qiara Media. 
Hidayat, Sholeh. 2017. Pengembangan Guru profesional. Serang : PT. Remaja Rosdakarya

Djamarah, Bahri Syaiful. (2010). Guru dan Anak Didik Dalam Interaksi Edukatif Edisi Revisi. Jakarta: Rineka Cipta.

Sugiono. (2014). Metode Penelitian Kuantitatif Kualitatif Dan R\&D. Bandung: Penerbit Alfabet

Mulyasa, E. (2013). Menjadi Guru Profesional Menciptakan Pembelajaran Kreatif dan
Menyenangkan. Bandung: PT Remaja Rosdakarya

Meda Yuliani, dkk. (2020). Pembelajaran Daring Untuk Pendidikan: Teori dan Penerapan. Medan: Yayasan Kita Menulis

Sri Gusty, dkk. (2020). Belajar Mandiri: Pembelajaran Daring di Tengah Pandemi Covid-19. Medan: Yayasan Kita Menulis Affandi, Muhajir. (2017). Teknologi Informasi dan Komunikasi. Kuningan: Yayasan Nurul Huda. 